\title{
Damage-Induced Activation of ERK1/2 in Cochlear Supporting Cells Is a Hair Cell Death-Promoting Signal That Depends on Extracellular ATP and Calcium
}

\author{
Manuela Lahne and Jonathan E. Gale \\ UCL Ear Institute and Department of Physiology, University College London, London WC1X 8EE, United Kingdom
}

\begin{abstract}
Acoustic overstimulation and ototoxic drugs can cause permanent hearing loss as a result of the damage and death of cochlear hair cells. Relatively little is known about the signaling pathways triggered by such trauma, although a significant role has been described for the c-Jun N-terminal kinase [one of the mitogen-activated protein kinases (MAPKs)] pathway. We investigated the role of another MAPK family, the extracellularly regulated kinases 1 and 2 (ERK1/2) during hair cell damage in neonatal cochlear explants. Within minutes of subjecting explants to mechanical damage, ERK1/2 were transiently activated in Deiters' and phalangeal cells but not in hair cells. The activation of ERK1/2 spread along the length of the cochlea, reaching its peak 5-10 min after damage onset. Release of extracellular ATP and the presence of functional connexin proteins were critical for the activation and spread of ERK1/2. Damage elicited an intercellular $\mathrm{Ca}^{2+}$ wave in the hair cell region in the first seconds after damage. In the absence of $\mathrm{Ca}^{2+}$ influx, the intercellular $\mathrm{Ca}^{2+}$ wave and the magnitude and spread of ERK1/2 activation were reduced. Treatment with the aminoglycoside neomycin produced a similar pattern of ERK1/2 activation in supporting cells surrounding pyknotic hair cells. When ERK1/2 activation was prevented, there was a reduction in the number of pyknotic hair cells. Thus, activation of ERK1/2 in cochlear supporting cells in vitro is a common damage signaling mechanism that acts to promote hair cell death, indicating a direct role for supporting cells in regulating hair cell death.
\end{abstract}

Key words: cochlea; ototoxicity; calcium signaling; purinergic receptors; cell-cell communication; ERK

\section{Introduction}

In the cochlea, sensory hair cells transduce sound stimuli into neural signals. Noise trauma or ototoxic insults cause damage and death of those cells, and in mammals hair cells cannot be replaced (Chardin and Romand, 1995). The failure to replace hair cells results in permanent hearing loss and deafness. To date we know relatively little about the signaling pathways triggered by noise trauma or ototoxins, such as aminoglycoside antibiotics (Forge and Schacht, 2000). One area of investigation has been the c-Jun N-terminal kinase [JNK; one of the mitogen-activated protein kinases (MAPKs)] pathway. JNK has been shown to be activated in hair cells as a result of aminoglycoside- and noiseinduced damage. Moreover, pharmacological prevention of JNK activation protects against hearing loss from those ototoxic insults (Pirvola et al., 2000; Wang et al., 2003; Matsui et al., 2004). Other members of the MAPK family, the extracellularly regulated kinases 1 and 2 (ERK1/2), can be activated in response to cellular stress (Sachsenmaier et al., 1994). In many cases, ERK1/2 activation is thought to act to promote cell survival (Xia et al., 1995;

\footnotetext{
Received 0ct. 31, 2007; revised Feb. 29, 2008; accepted March 28, 2008.

This work was supported by a Medical Research Council-funded studentship (M.L.), Wellcome Trust Grant 57261 , and a Royal Society University Research Fellowship (J.E.G.). We thank Drs. Andrew Forge and Mark Warchol for critical comments on this manuscript.

Correspondence should be addressed to Dr. Jonathan E. Gale, UCL Ear Institute, 332 Gray's Inn Road, London WC1X 8EE, UK. E-mail: j.e.gale@ucl.ac.uk.

DOI:10.1523/JNEUROSCI.4914-07.2008

Copyright $\odot 2008$ Society for Neuroscience $\quad$ 0270-6474/08/284918-11\$15.00/0
}

Arthur et al., 2006). Less is known about the role of ERK1/2 during cochlear toxicity. Inhibiting ERK1/2 activation in cochlear explants was in itself capable of causing a loss of outer hair cells (OHCs), and in addition, there was an enhancement of gentamicin-induced toxicity (Battaglia et al., 2003). The properties and mechanism of ERK1/2 activation were not investigated directly, and there was no description of the effect on inner hair cells (IHCs), the primary afferent sensory cells of the cochlea.

Recently, we showed that mechanical damage to cochlear hair cells triggers changes in intracellular calcium $\left(\left[\mathrm{Ca}^{2+}\right]_{\mathrm{i}}\right)$ signaling in the form of intercellular $\mathrm{Ca}^{2+}$ waves (Gale et al., 2004; Piazza et al., 2007). ATP release from damaged cells triggers $\mathrm{Ca}^{2+}$ mobilization and a regenerative release of ATP from supporting cells (Gale et al. 2004), perhaps via connexin hemichannels (Zhao et al., 2005). In this way, cochlear supporting cells can be considered to act like glial cells because astrocytes respond identically to mechanical stimulation by releasing ATP (Newman, 2001). When astrocytes were subjected to stretch-induced injury, ERK1/2 activation occurred in an autocrine manner via purinergic $\mathrm{P} 2$ receptors. The activation was reduced when $\mathrm{Ca}^{2+}$ influx was diminished (Neary et al., 2003). Signaling events downstream of intercellular $\mathrm{Ca}^{2+}$ waves in the mammalian cochlea are unknown, although the activation of JNK signaling has been indicated (Gale et al., 2004). In the present study, we address whether the MAPK family members ERK1/2 are activated by damage in the neonatal mammalian cochlea; we examine the mechanisms of ERK1/2 activation in context of intercellular 

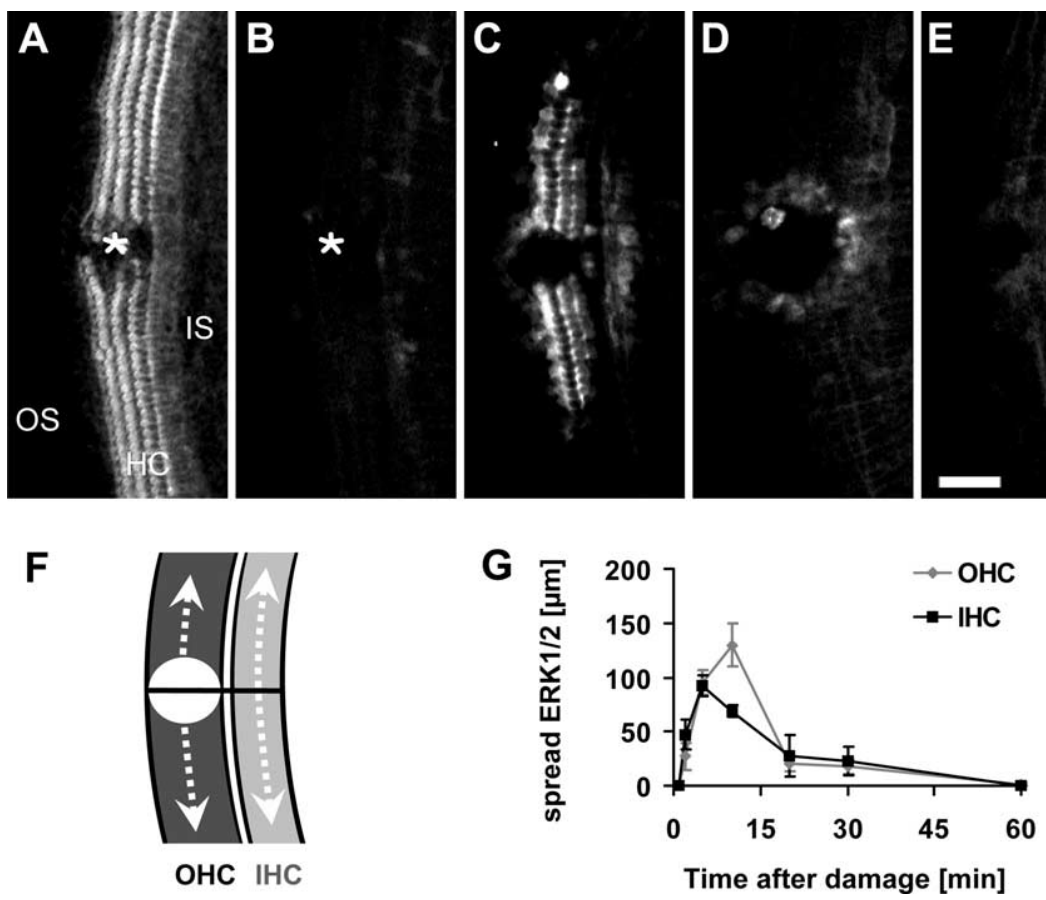

Figure 1. Spatiotemporal characteristics of damage-induced ERK1/2 activation in the organ of Corti. $\boldsymbol{A}$, Confocal $z$-stack average of a phalloidin-stained explant shows hair bundles of the three rows of $\mathrm{OHCS}$ and one row of IHCS. OS, Outer sulcus; IS, inner sulcus. Shown is a typical laser lesion or damage site (asterisk) induced with an $\mathrm{N}_{2}$ laser, 1 min after damage. $\boldsymbol{B}-\boldsymbol{E}$, Confocal $z$-stack averages immunostained for activated ERK1/2 at $1 \mathrm{~min}(\boldsymbol{B}$; corresponding image to $\boldsymbol{A}), 10 \mathrm{~min}(\boldsymbol{C}), 30 \mathrm{~min}(\boldsymbol{D})$, and $60 \mathrm{~min}$ (E) after damage. $\boldsymbol{F}$, The distance of ERK1/2 activation along the $\mathrm{HC}$ rows was quantified using linescan analysis. The diagram indicates the analysis using lines of width: 38 and $25 \mu \mathrm{m}$ for $\mathrm{OHC}$ and $\mathrm{IHC}$ regions, respectively placed along the hair cell rows (dotted arrows). The white circle represents the damage area. G, Spread of ERK1/2 activation as a function of time after damage. Data are presented as mean \pm SEM. $n \geq 4$. Scale bar, $50 \mu \mathrm{m}$.

$\mathrm{Ca}^{2+}$ waves and the role of ERK1/2 activation during cochlear trauma.

\section{Materials and Methods}

Cochlear isolation and culture. Cochlear coils were isolated from postnatal day 1 (P1) or P2 Sprague Dawley rats. The isolation was performed in accordance with United Kingdom Animals (Scientific Procedures) Act of 1986. Briefly, auditory bullae were removed and transferred into medium 199 (M199; Invitrogen, Paisley, UK) supplemented with penicillin $(10 \mathrm{U} / \mathrm{ml})$ and fungizone $(25 \mathrm{ng} / \mathrm{ml})$. To access the cochlea, the bulla was opened and freed from the surrounding cartilage. Stria vascularis and Reissner's membrane were removed and the cochlea cut into three pieces or turns. The cochlear turns were placed onto Cell-Tak cell and tissue adhesive (BD Biosciences, San Jose, CA)-coated MatTek (Ashland, MA) dishes. For coating, cell adhesive was diluted to $70 \mu \mathrm{g} / \mathrm{ml}$ in $0.1 \mathrm{~mm}$ $\mathrm{NaHCO}_{3}$. The explants were incubated in DMEM/F12 (Invitrogen) that was supplemented with 5\% FBS (Invitrogen) and maintained at $37^{\circ} \mathrm{C}$ in a $5 \% \mathrm{CO}_{2} / 95 \%$ air atmosphere. After $1 \mathrm{~d}$ in culture, explants designated to study the mechanism of ERK1/2 activation or changes in $\mathrm{Ca}^{2+}$ levels were incubated in HBHBSS $\left(\mathrm{Ca}^{2+} / \mathrm{Mg}^{2+}\right.$-free HBSS supplemented with $10 \mathrm{~mm}$ HEPES, $1 \mathrm{mM} \mathrm{Ca}^{2+}$, and $1 \mathrm{mM} \mathrm{Mg}^{2+}$ ) for the duration of the experiment. In some experiments, cochlear explants were incubated with inhibitors: U0126 (10 $\mu \mathrm{m}$; Merck Biosciences, Nottingham, UK), Raf kinase inhibitor 1 (10 $\mu \mathrm{M}$; Merck Biosciences), apyrase (40 U/ml), carbenoxolone $(75 \mu \mathrm{M})$, or a combination of apyrase and carbenoxolone, in each case for $30 \mathrm{~min}$, and BAPTA-AM for $90 \mathrm{~min}$ before the experiment. The inhibitors were also maintained in the buffer during the damage protocol. U0126, Raf kinase inhibitor 1, and carbenoxolone were dissolved in dimethylsulfoxide (DMSO), and BAPTA-AM was dissolved in $10 \%$ pluronic in DMSO, for which appropriate vehicle controls were performed. Some experiments were performed in zero- $\mathrm{Ca}^{2+} \mathrm{HBHBSS}$ (zero $\mathrm{Ca}^{2+}$ ), in which $\mathrm{Ca}^{2+} / \mathrm{Mg}^{2+}$ free-HBSS was supplemented with 1

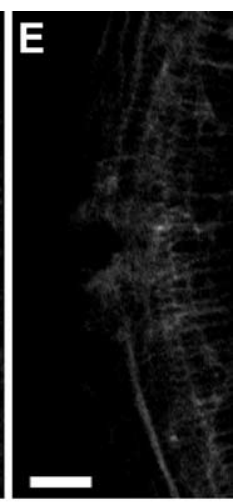

mM EGTA and $2 \mathrm{~mm} \mathrm{Mg}^{2+}$. The explants were changed into buffer containing zero $\mathrm{Ca}^{2+} \sim 5$ min before onset of the damage stimuli.

Laser damage. Laser damage was used to investigate the time course and mechanism of damage-induced activation of ERK1/2. The lesions were induced using a Micropoint system (Photonic Instruments, Arlington Heights, IL). Briefly, the technique is based on a pulsed nitrogen laser (VSL-337 ND-S; Laser Science, Franklin, MA) emitting energy at $337 \mathrm{~nm}(70 \mathrm{~kW}$ peak output, $70 \mathrm{~ns}$ ) that pumps a coumarin-filled dye cell. The dye emits a $440 \mathrm{~nm}$ beam onto steering mirrors that align and focus the beam through the lens onto the specimen. The intensity of the emitted light and thus the size of the lesions were adjusted with a graded neutral density attenuator plate. The laser beam was focused through a $40 \times 1.3$ numerical aperture (NA) Zeiss (Welwyn Garden City, UK) Fluar objective (oilimmersion) onto the second row of outer hair cells. Several pulses were sufficient to induce a lesion as shown in Fig. 1 A.

Needle damage. For some experiments, we required visualization of a larger area of the cochlear explants, and for this a $20 \times 0.75$ NA Zeiss Fluar objective was used. The laser ablation technique was less effective with the lower magnification/NA lenses, and therefore we induced mechanical trauma using a microneedle. The tip of the microneedle was positioned $15 \mu \mathrm{m}$ above the focal plane of the hair bundle of the second row of OHCs. Damage was induced by lowering the microneedle $\sim 60 \mu \mathrm{m}$ using a remote-controlled piezoelectric manipulator (Scientifica, Uckfield, UK), holding it there for $2 \mathrm{~s}$, and returning it to its original position above the tissue.

Local ATP application. In a subset of experiments, the purine nucleotide ATP $(10$ or $100 \mu \mathrm{M})$ diluted in HBHBSS, was exogenously pressure applied using a micropipette connected to a picospritzer. Micropipettes with a tip diameter of $2 \mu \mathrm{m}$ were pulled using a two-step electrode puller (Narishige, Tokyo, Japan). Nucleotides were locally applied for $10 \mathrm{~s}$ with a pressure of 6 psi, which did not activate mechanically induced $\mathrm{Ca}^{2+}$ signals. At 5 min after application, explants were fixed for immunocytochemical labeling.

ERK1/2 immunocytochemistry. Cochlear explants were fixed at various time points $(1,2,5,10,20,30$, and $60 \mathrm{~min})$ after $\mathrm{N}_{2}$-laser damage $(4 \%$ paraformaldehyde for $45 \mathrm{~min}$ ). Fixed explants were washed three times in PBS $(0.1 \mathrm{M}$ ), blocked with $10 \%$ goat serum in PBS (with $0.1 \%$ Triton $\mathrm{X}-100$ ) for $1 \mathrm{~h}$, and incubated overnight at $4^{\circ} \mathrm{C}$ with a mouse monoclonal antibody specific to dually phosphorylated ERK1/2 (1:1000; M8159; Sigma-Aldrich, St. Louis, MO). Anti-ERK1/2 was visualized with $2 \mu \mathrm{g} / \mathrm{ml}$ Alexa 488 goat anti-mouse antibody ( $2 \mathrm{~h}$ at room temperature). The explants were counterstained with $4^{\prime}, 6^{\prime}$-diamidino-2-phenylindole (DAPI; $1 \mu \mathrm{M} ; 1 \mathrm{~h}$ at room temperature) and Alexa 546- or Alexa 633phalloidin ( $33 \mathrm{~nm} ; 1 \mathrm{~h}$ at room temperature). Z-stack images of $1.13 \mu \mathrm{m}$ thickness each were acquired with a Zeiss LSM 510 confocal microscope using $20 \times$ Plan-Apochromat (NA, 0.75), 40× Plan-Neofluar (NA, 1.3) or $63 \times$ Plan-Apochromat (NA, 1.4) lenses. Laser excitation lines at 405 (DAPI), 488 (Alexa 488), and 543 and $633 \mathrm{~nm}$ (Alexa 546 and Alexa 633, respectively) were used. To semiquantify the activation of ERK1/2, images were acquired and prepared with the same acquisition settings. Averages were prepared using Lucida software (Andor, Belfast, UK), and the extent of the ERK1/2 spread was analyzed performing a line scan of the intensity profile along the rows of Deiters' cells and separately along the inner phalangeal cell rows using MetaMorph software (Molecular Devices, Sunnyvale, CA). To determine the cellular localization of activated ERK1/2, orthogonal projections and three-dimensional reconstructions were prepared using Zeiss LSM software. 
Intracellular $\mathrm{Ca}^{2+}$ imaging. Changes in the cytoplasmic $\mathrm{Ca}^{2+}$ concentrations were measured in cochlear explants using the ratiometric $\mathrm{Ca}^{2+}$. sensitive dye fura-2 AM. Fura-2 AM was dissolved in $10 \%$ pluronic in DMSO to a $3 \mathrm{~mm}$ stock solution. Explants were loaded with $3 \mu \mathrm{M}$ fura-2 AM in DMEM/F12 for 40-50 min at $37^{\circ} \mathrm{C}$ in a $5 \% \mathrm{CO}_{2} / 95 \%$ air atmosphere, washed four times in HBHBSS, and then placed at $25^{\circ} \mathrm{C}$ for $20 \mathrm{~min}$. Experiments were performed at room temperature $\left(20-23^{\circ} \mathrm{C}\right)$ in HBHBSS. Fura-2 AM was alternately excited at 340 and $380 \mathrm{~nm}$ using a monochromator (Kinetic Imaging, Nottingham, UK). Epifluorescent light was passed through a $490 \mathrm{~nm}$ dichroic mirror and a $510 \mathrm{~nm}$ long-pass filter, and images were captured on a Sensicam LE 12 bit cooled CCD camera (PCO, Kelheim, Germany). IQ software (Andor) was used to control illumination and image capture. Needle damage was induced after collecting baseline data for $\sim 20 \mathrm{~s}$. Typically, three lesions, at least $300 \mu \mathrm{m}$ apart, were performed on a cochlear explant. The first "control" lesion was performed in HBHBSScontaining vehicle, and the second and third damage stimuli were performed in the presence of either BAPTA-AM $(90 \mathrm{~min})$ or zero $\mathrm{Ca}^{2+}$ $(\sim 5 \mathrm{~min})$.

Changes in the $340 / 380$ ratio $(\Delta R)$ are proportional to changes in cytoplasmic $\mathrm{Ca}^{2+}$ levels $\left(\left[\mathrm{Ca}^{2+}\right]_{\mathrm{c}}\right)$. Emission intensities for 340 and 380 excitation were determined in regions of interest placed 40-60 (50), 80-100 (90), and 120-140 (130) $\mu \mathrm{m}$ from the damage site (along the hair cell rows in both directions) using MetaMorph and exported into Microsoft (Redmond, WA) Excel, where ratios were calculated after background subtraction. Maximum $\mathrm{Ca}^{2+}$ changes were determined for comparison between control and drug treatment.

Neomycin-induced hair cell damage. Neomycin was used to target hair cells specifically and investigate ERK1/2 signaling. In mouse cochlear explants, the basal to apical coil sensitivity of hair cells to aminoglycosides observed in vivo is maintained (Richardson and Russell, 1991). Initial experiments in our laboratory confirmed that the differential sensitivity persisted in rat cochlear explants (data not shown). Therefore, only basal and middle turns were used for the present experiments. Neomycin (1 mM; 0.001\% DMSO vehicle), neomycin with $10 \mu \mathrm{M}$ U0126 (0.001\% DMSO), and neomycin with the inactive analog U0124 (10 $\mu \mathrm{M}$; 0.001\% DMSO; Cell Signaling Technology, Danvers, MA) were applied to cochlear explants. Test solutions were equilibrated at $37^{\circ} \mathrm{C}\left(5 \% \mathrm{CO}_{2}\right)$ for $20 \mathrm{~min}$ before use. Cochlear explants were washed four times in test solution before incubation at $37^{\circ} \mathrm{C}$ in $5 \% \mathrm{CO}_{2} / 95 \%$ air for $8 \mathrm{~h}$. Culture media were replenished at $4 \mathrm{~h}$ to avoid breakdown of test substances. After $8 \mathrm{~h}$ of incubation, explants were fixed for immunocytochemical labeling.

Confocal $z$-stacks $(\sim 45 \mu \mathrm{m}$; slice separation, $0.86 \mu \mathrm{m})$ were acquired from two or three regions $(460 \times 230 \mu \mathrm{m})$ per cochlear explant. The number of pyknotic and healthy-appearing inner hair cell nuclei were determined using DAPI-labeled confocal $z$-stack images throughout the thickness of the cochlear epithelium. Condensed morphology and increased intensity were used to determine pyknosis. In some cases, there were extruded pyknotic nuclei, and these were included in the counts. Data are expressed as the number of pyknotic inner hair cell nuclei per $100 \mu \mathrm{m}$.

In the mature mammalian cochlea, hair cell loss triggered by aminoglycoside treatment results in the formation of what have been termed epithelial "scars" (Forge, 1985; Raphael and Altschuler, 1991). In these neonatal cochlear preparations, we have confirmed that neomycin treatment results in the formation of such scars at the epithelial surface in the place of inner hair cells (supplemental Fig. 1, available at www. jneurosci.org as supplemental material).

Chemicals. Fura-2 AM, BAPTA-AM, and AlexaFluor-conjugated secondary antibodies were from Invitrogen. All other chemicals were obtained from Sigma-Aldrich unless otherwise stated.

Sample numbers and statistical analysis. Data are presented as mean \pm SEM. Statistical analysis was performed using unpaired Student's $t$ tests.

\section{Results}

Spatiotemporal characteristics of damage-induced ERK1/2 activation

To examine damage-induced signaling in the mammalian cochlea, an $\mathrm{N}_{2}$ laser was used to ablate the hair cell region of neonatal cochlear explants, allowing precise timing of onset and control of the damage area. The ablation that results from this in vitro stimulus is qualitatively reminiscent of the lesion produced at the extremes of noise stimulation in vivo (Wang et al., 2002). Using this method, we examined the spatiotemporal activation of ERK1/2 by fixing cochlear explants at various time points after laser ablation and staining with an antibody raised against the dually phosphorylated, i.e., activated form of ERK1/2. Figure 1 shows the pattern of ERK1/2 activation at 1, 10, 30, and $60 \mathrm{~min}$ after damage. There was little or no activation of ERK1/2 at $1 \mathrm{~min}$ after damage (Fig. $1 \mathrm{~B}$ ). On the contrary, $10 \mathrm{~min}$ after ablation a distinct pattern of phosphorylated ERK1/2 staining was observed with preferential activation occurring along the sensory hair cell rows (Fig. 1C). By $30 \mathrm{~min}$, ERK1/2 activation was restricted to cells that were adjacent or very close to the damage site, and by 60 min, ERK1/2 activation was back to baseline levels. To quantify the spread of ERK1/2 activation, we performed a linescan analysis 

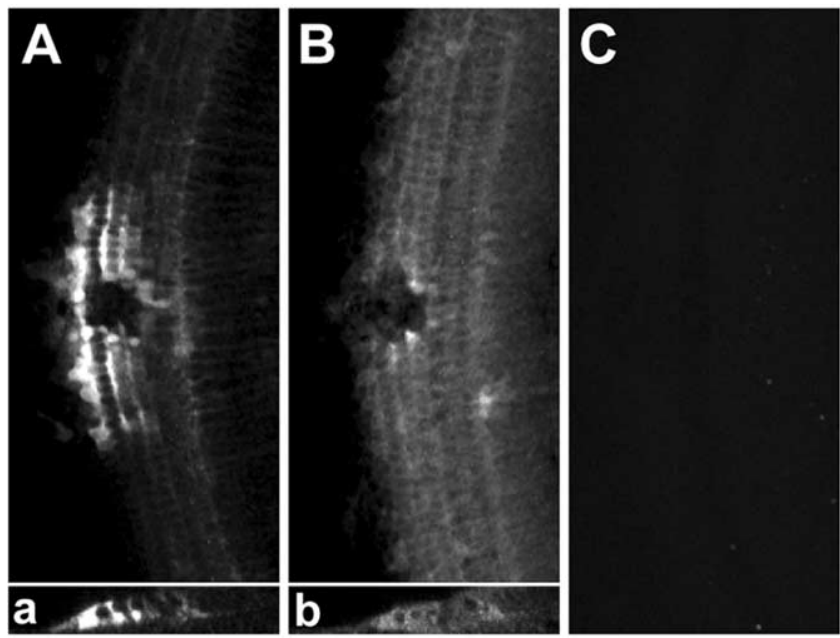

Figure 3. Damage-induced activation of ERK1/2 occurs via an RAF1- and MEK1/2-dependent mechanism. $A$-C, Confocal $Z$-stack averages of activated ERK $1 / 2$ at 5 min after damage in a control damaged explant $(\boldsymbol{A})$ and those treated with RAF 1 inhibitor $\mathrm{I}$ $(\boldsymbol{B})$ or the MEK1/2 inhibitor U0126 (C) $\boldsymbol{a}, \boldsymbol{b}$, Orthogonal projections of activated ERK1/2 in control ( $\boldsymbol{a}$ ) and presence of RAF1 inhibitor I (b). $\boldsymbol{C}^{\prime}$, Same explant as $\boldsymbol{C}$, showing damage site and hair bundles stained with phalloidin. $n=3$. Scale bar, $50 \mu \mathrm{m}$.
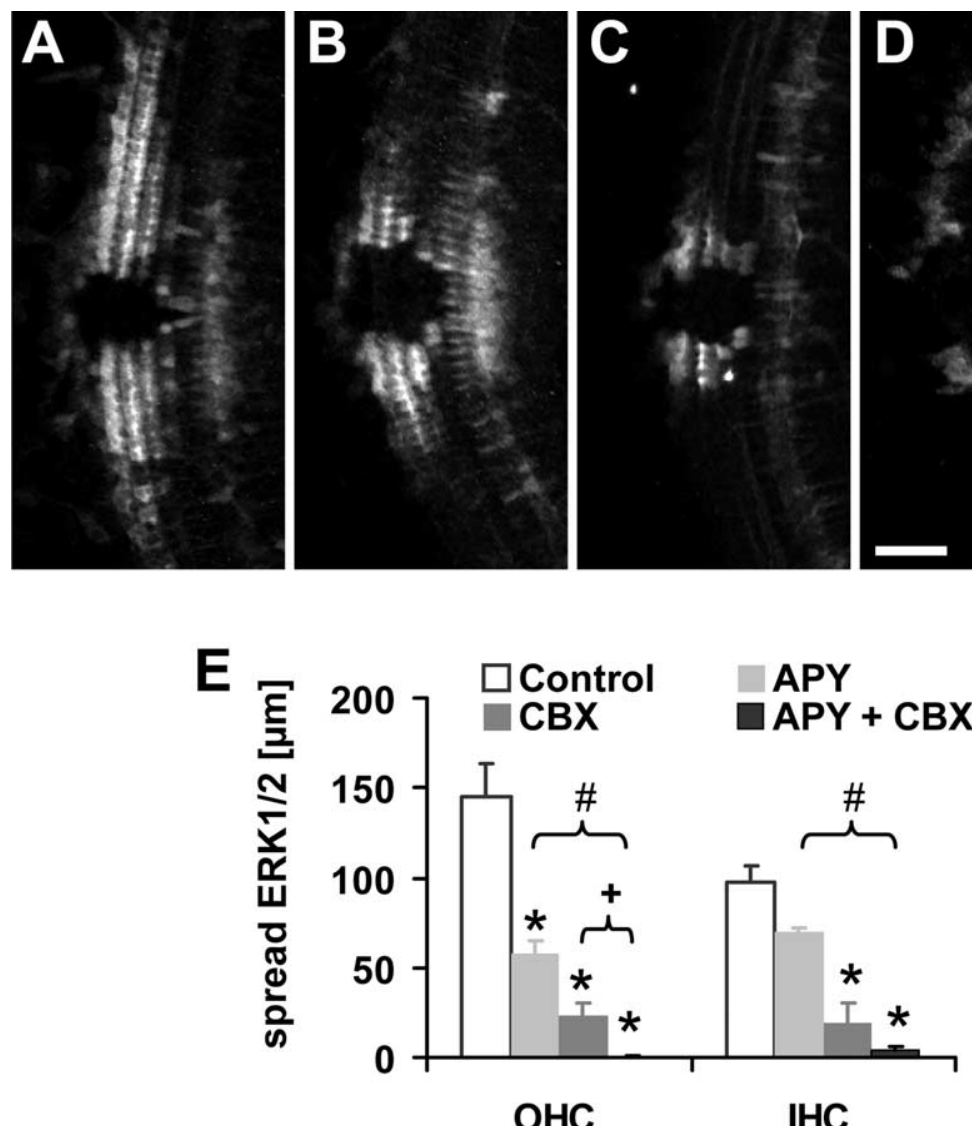

Figure 4. Mechanisms of damage-induced ERK $1 / 2$ signaling. $A-D$, Confocal $z$-stack averages of activated ERK $1 / 2$ at $5 \mathrm{~min}$ after laser damage in control explant $(\boldsymbol{A})$ or in the presence of $40 \mathrm{U} / \mathrm{ml}$ apyrase (APY; $\boldsymbol{B}), 75 \mu \mathrm{m}$ carbenoxolone (CBX; $\boldsymbol{C}$ ), or APY and $C B X$ applied together (D).E, ERK1/2 spread measured using linescan analysis for the conditions in $\boldsymbol{A}-\boldsymbol{D}$. Data are presented as mean \pm SEM. ${ }^{*} p<0.05$ between treated and control; ${ }^{\#} p<0.05$ between APY and APY plus CBX; ${ }^{+} p<0.05$ between CBX and APY plus (BX; $n=9$ (control); $n=5$ (APY); $n=4$ (CBX); $n=4$ (APY plus CBX); Student's $t$ test. Scale bar, $50 \mu \mathrm{m}$.

along the length of the sensory hair cell rows. Lines were placed along the regions formed by the two types of hair cell, the outer and inner hair cells (Fig. $1 \mathrm{~F}$ ). The outer hair cell region is composed of OHCs intercalated with equal numbers of their surrounding sup-
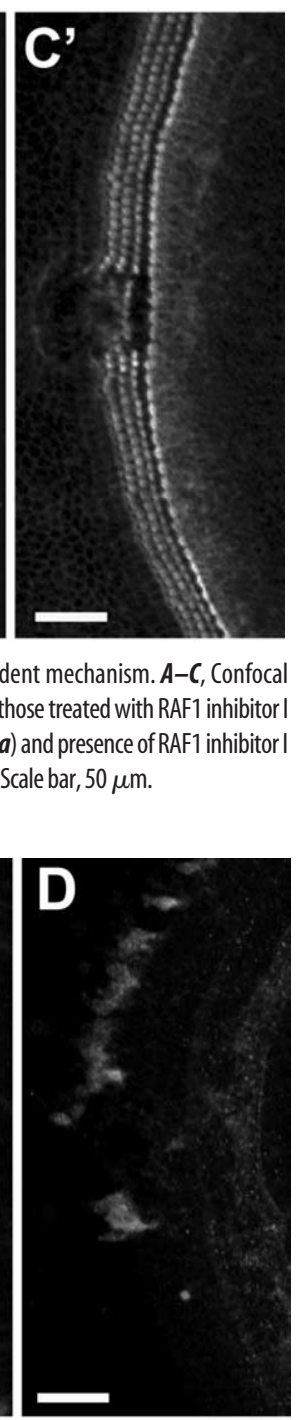

porting cells, Deiters' cells. In the inner hair cell region, there are two types of supporting cells, the inner phalangeal and border cells along with the IHCs. ERK1/2 activation was observed to spread from the edge of the damage site as a function of time after ablation (Fig. $1 G$ ). In the outer hair cell region, we observed that ERK1/2 were first activated at $2 \mathrm{~min}$ after damage, and by that time the activation had spread $27 \pm 12$ $\mu \mathrm{m}(n=9)$. Activated ERK1/2 spread farther from the damage site, reaching a maximum of $115 \pm 31 \mu \mathrm{m} 10 \mathrm{~min}$ after damage $(n=5)$. The spread then declined, such that ERK $1 / 2$ activation was restricted to cells lining the damage site 30 min after damage ( $17 \pm 7 \mu \mathrm{m} ; n=4$ ) (Fig. $1 D, G)$, and at $60 \mathrm{~min}$, ERK1/2 activation returned to baseline levels (Fig. $1 E, G$ ). A similar transient activation pattern was seen in the inner hair cell region. ERK1/2 activation was first observed 2 min after damage extending $47 \pm 13 \mu \mathrm{m}(n=9)$. In contrast to the outer hair cell region, ERK1/2 spread reached a maximum 5 min after damage ( $92 \pm 10 \mu \mathrm{m} ; n=21)$, and by $30 \mathrm{~min}$ after damage, it was restricted to the cells in immediate proximity to the damage site $(22 \pm 13 \mu \mathrm{m} ; n=4)($ Fig. $1 D, G)$. At 60 min after damage, ERK1/2 activation returned to baseline in the inner hair cell region.

Orthogonal projections and threedimensional reconstruction of confocal image stacks revealed the cell-specific nature of the damage-induced ERK1/2 activation (Fig. 2). In the outer hair cell region, three rows of phalangeal processes of Deiters' cells projecting to the apical surface of the epithelium can be seen (Fig. $2 A, D, E$ ). Activated ERK1/2-positive cell bodies and nuclei of Deiters' cells were observed adjacent to unlabeled OHCs (Fig. 2C-E). Similarly, the phalangeal cells that surround IHCs exhibited ERK1/2 activation, whereas neighboring inner hair cells did not (Fig. 2B). In some cases, we observed activation in pillar cells, another supporting cell type. In contrast to the pattern of ERK1/2 activation that spread along the Deiters' and phalangeal cells, the activation in pillar cells always remained restricted to the proximity of the damage site. The subcellular distribution of activated ERK1/2 is thought to be crucial for its downstream effects. Activated ERK1/2 targets various cytoplasmic proteins, including myosin light chain kinase, m-calpain, and phospholipase A2 (Lin et al., 1993; Nguyen et al., 1999; Glading et al., 2004), whereas the translocation of activated ERK1/2 to the nucleus results in the transcriptional regulation of immediate early genes (Hodge et al., 1998). In the cochlea, 10 min after damage, activated ERK $1 / 2$ is found in the nucleus and in the cytoplasm of supporting cells (Fig. $2 C-E$ ). 


\section{ERK1/2 activation occurs in a classical manner via the activation of $\mathrm{c}-\mathrm{RAF}$ and MEK1/2}

ERK1/2 activation typically occurs after stimulation of cell surface receptors that activate MAPK kinase kinases, such as RAFs, which subsequently phosphorylate the MAPK kinases, MEK1/2. MEK1/2 then dually phosphorylate and activate the MAPKs, ERK1/2. Here, we determined whether damage-induced activation of ERK1/2 was also mediated through this classical activation cascade using a cell-permeant inhibitor of RAF1 (Lackey et al., 2000) and the MEK1/2 inhibitor U0126 (Favata et al., 1998). When RAF1 was inhibited, the damage-induced activation of ERK1/2 was restricted to a few supporting cells adjacent to the damage site (Fig. $3 B$ ). In addition, there was an increase in the basal level of ERK $1 / 2$ activation observed in the cytoplasm of hair cells and supporting cells throughout the explant, i.e., in undamaged areas. Application of the MEK1/2 inhibitor U0126 abolished basal and damageinduced activation of ERK1/2 (Fig. 3C,D).

\section{Mechanism of damage-induced ERK1/2 activation 1: ATP and spread}

In astrocytes, stretch injury triggers the release of extracellular ATP, which acts on $\mathrm{P} 2$ receptors to activate ERK1/2 (Neary et al., 2003). We have shown that hair cell damage triggers the formation of an intercellular $\mathrm{Ca}^{2+}$ wave in cochlear explants that is dependent on the regenerative release of ATP (Gale et al., 2004). Here we tested whether the damage-induced release of ATP was required for the activation and spread of the ERK1/2 signal in cochlear explants. The ATP-degrading enzyme apyrase (40 $\mathrm{U} / \mathrm{ml}$ ) significantly reduced the spread of ERK1/2 activation from the damage site along the rows of Deiters' cells ( $58 \pm 7 \mu \mathrm{m} ; n=$ 5) compared with untreated controls $(148 \pm 18 \mu \mathrm{m} ; n=9)$ (Fig. $4 A, B, E)$. Apyrase also affected the spread of ERK $1 / 2$ activation along the phalangeal cells in the inner hair cell region [97 $\pm 9 \mu \mathrm{m}$ $(n=9)$ reduced to $69 \pm 2 \mu \mathrm{m}(n=5) ; p=0.074]$ (Fig. $4 A, B, E)$. In all cases, apyrase treatment did not completely abolish ERK1/2 activation. It is possible that insufficiency reduced the effectiveness of the enzyme close to the damage site. However, another possibility is that spread of ERK1/2 activation along Deiters' and phalangeal cells can also occur in an extracellular ATPindependent manner. Extensive gap junction plaques and efficient coupling are observed in both of these cell types (SantosSacchi, 1986; Kikuchi et al., 1995; Forge et al., 2003; Jagger and Forge, 2006). Therefore we tested whether gap junctions could mediate the damage-induced spread of ERK1/2 activation using carbenoxolone $(75 \mu \mathrm{M})$, a gap junction blocker. Carbenoxolone significantly reduced the spread of ERK1/2 activation along the rows of Deiters' cells $(23 \pm 7 \mu \mathrm{m} ; n=4)$ and the rows of phalangeal cells $(19 \pm 11 \mu \mathrm{m} ; n=4)$ (Fig. $4 C, E)$, indicating that gap junctions are involved in the spread of a signal that activates ERK1/2. When apyrase and carbenoxolone were applied together, ERK1/2 activation was almost completely abolished in the Deiters' and phalangeal cells. In some explants, under those conditions, activation was observed in Hensen's cells, a supporting
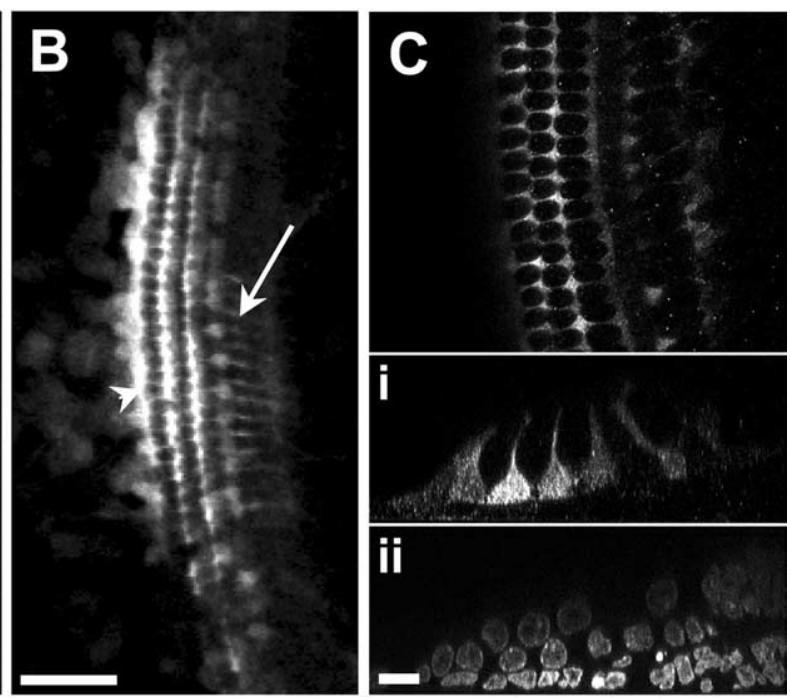

Figure 5. Local application of ATP mimics the damage-induced ERK1/2 activation. $A, B$, Confocal $z$-stack averages of activated

cell type situated lateral to the outer row of Deiters' cells (Fig. $4 D)$. The combined apyrase and carbenoxolone treatment resulted in significant reduction in the ERK1/2 signal spread when compared with apyrase alone and carbenoxolone alone for the outer hair cell region. In the inner hair cell region, there was a significant reduction with the combined treatment compared with apyrase treatment alone (Fig. $4 E$ ). These results suggest that both ATP-dependent and gap junction-dependent mechanisms coexist and contribute to the damage-induced activation of ERK1/2 in the mammalian cochlea.

\section{Extracellular ATP selectively and sufficiently activates ERK1/2 in supporting cells}

Exogenous application of ATP was sufficient to induce ERK1/2 activation. ATP (10 or $100 \mu \mathrm{M}$ ) was locally applied for $10 \mathrm{~s}$ in an attempt to mimic the damage-induced release of ATP from a group of cells. Five minutes after a $10 \mathrm{~s}$ application of $10 \mu \mathrm{M}$ ATP, ERK1/2 activation was observed in a few Deiters' cells (Fig. $5 A$, arrowhead). In contrast, $5 \mathrm{~min}$ after application of $100 \mu \mathrm{M}$ ATP, activation was observed in numerous cells. Activation was consistently observed along the length of the cochlea in the Deiters' and phalangeal cells surrounding hair cells but not in hair cells themselves (Fig. $5 \mathrm{~B}, \mathrm{Ci}$ ). The pattern of ERK1/2 activation and spread in response to $100 \mu \mathrm{M}$ ATP was remarkably similar to that of damage-induced ERK1/2 activation (Fig. 1C). Thus, a brief exogenous application of ATP $(100 \mu \mathrm{M})$ is sufficient to activate ERK1/2 in supporting cells that surround hair cells, mimicking the spatiotemporal pattern observed during damage-induced activation of ERK1/2.

\section{Mechanism of ERK1/2 activation 2: dependence on $\left[\mathrm{Ca}^{2+}\right]_{\mathrm{i}}$} To test whether changes in $\left[\mathrm{Ca}^{2+}\right]_{\mathrm{i}}$ are necessary for the damageinduced ERK1/2 activation in supporting cells, we modified the damage regimen to allow us to record changes in $\left[\mathrm{Ca}^{2+}\right]_{\mathrm{i}}$. Previous examination of the damage-induced $\mathrm{Ca}^{2+}$ wave used a micropipette to damage a single hair cell, and analysis was dominated by signals from the outer sulcus region, which includes Hensen's and Claudius' cells (Gale et al., 2004; Piazza et al., 2007). 

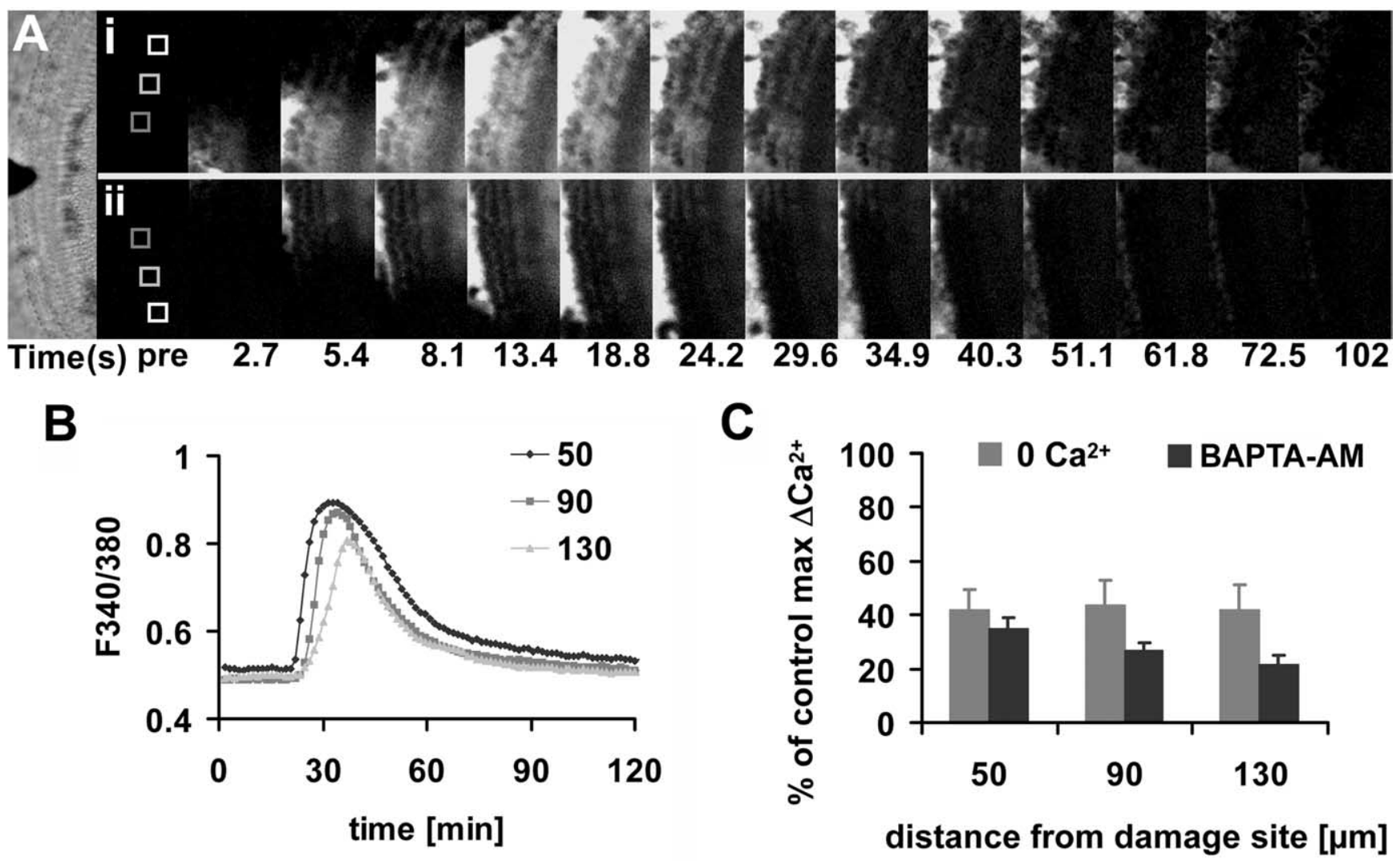

Figure 6. Activation of a damage-induced $\mathrm{Ca}^{2+}$ wave in the hair cell region: partial requirement for $\left[\mathrm{Ca}^{2+}\right]$ influx. $A$, Bright-field image of hair cell rows focused at the level of hair bundles, showing the microneedle used to damage hair cells. $\boldsymbol{i}$, ii, Time series of baseline-subtracted fura-2 AM 340/380 ratios showing damage-induced $\mathrm{Ca}^{2+}$ wave spread in the presence of 1 mM extracellular $\mathrm{Ca}^{2+}(\boldsymbol{i})$ and $\mathrm{Ca}^{2+}$ wave spread in zero $\mathrm{Ca}^{2+}$ (ii). Regions of interest $(20 \times 20 \mu \mathrm{m})$ were placed 50, 90, and $130 \mu \mathrm{m}$ from the damage site. $\boldsymbol{B}$, Fura-2 AM $340 / 380$ ratio changes as a function of time for regions of interest displayed in Ai. C, Maximum $\left[\mathrm{Ca}^{2+}\right]_{i}$ changes in zero $\mathrm{Ca}^{2+}$ and in the presence of BAPTA-AM as a percentage of control levels and as a function of distance from the damage site.

Having observed ERK1/2 activation predominantly along the rows of Deiters' cells, we focused on determining the properties of the $\mathrm{Ca}^{2+}$ wave along the hair cell region using a microneedle to damage that region. Microneedle damage elicited a $\mathrm{Ca}^{2+}$ wave that spread into the outer sulcus region as described previously. The $\mathrm{Ca}^{2+}$ wave also spread through the hair cell region, where cells local to the damage site responded with a rise in $\left[\mathrm{Ca}^{2+}\right]_{\mathrm{i}}$ and then an intercellular $\mathrm{Ca}^{2+}$ wave spread from the damage site to cells farther along the length of the cochlea (Fig. 6A). We quantified the spread of the intercellular $\mathrm{Ca}^{2+}$ wave by measuring fura- $2 \mathrm{AM}$ ratio changes in $20 \times 20 \mu \mathrm{m}$ regions of interest placed along the hair cell region 50, 90, and $130 \mu \mathrm{m}$ from the damage site. Damage triggered a transient rise in $\left[\mathrm{Ca}^{2+}\right]_{\mathrm{i}}$ that recovered to baseline within $\sim 2 \mathrm{~min}$. The maximum change in $\mathrm{Ca}^{2+}$ was reduced as a function of distance from the damage site (Fig. $6 \mathrm{~B}$ ). ATP is known to bind to two main types of $\mathrm{P} 2$ receptor: the ionotropic $\mathrm{P} 2 \mathrm{X}$ receptors and the G-protein coupled $\mathrm{P} 2 \mathrm{Y}$ receptors. To test whether $\mathrm{Ca}^{2+}$ entry through $\mathrm{P} 2 \mathrm{X}$ receptors is required for ERK1/2 activation, we repeated the damage in zero$\mathrm{Ca}^{2+}$ conditions (with $1 \mathrm{~mm}$ EGTA present). In the absence of extracellular $\mathrm{Ca}^{2+}$, the maximum $\mathrm{Ca}^{2+}$ change was reduced to $\sim 40 \%$ of control levels at all three distances measured (Fig. $6 \mathrm{~A}, \mathrm{C})$. In the absence of $\mathrm{Ca}^{2+}, \mathrm{ERK} 1 / 2$ was still activated, but the signal spread was significantly reduced at $10 \mathrm{~min}$ after damage from $94 \pm 20 \mu \mathrm{m}$ in controls to $44 \pm 11 \mu \mathrm{m}$ in zero-Ca ${ }^{2+}$ (Fig. $7 A, B, E)$. The level of activation in zero- $\mathrm{Ca}^{2+}$ was also apparently reduced, but this observation remains qualitative (Fig. $7 A, B$ ). The requirement for global changes in $\left[\mathrm{Ca}^{2+}\right]_{\mathrm{i}}$ was tested by incubating explants in $10 \mu \mathrm{M}$ BAPTA-AM for 90 min. BAPTA loading reduced the damage-induced maximum increase in $\left[\mathrm{Ca}^{2+}\right]_{\mathrm{i}}$ to a greater extent than zero- $\mathrm{Ca}^{2+}$ at all distances (Fig. $6 C$ ) but did not reduce ERK1/2 activation (Fig. 7C-E).

Blockade of ERK1/2 activation can reduce hair cell death in neomycin-treated cochlear explants

Aminoglycoside antibiotics are a useful method for selectively triggering hair cell death (Forge and Schacht, 2000), and recent work has suggested that a main entry site for these molecules is through the mechanoelectrical transduction channels (Gale et al., 2001; Marcotti et al., 2005). After 8 h of neomycin treatment, we observed ERK1/2 activation in supporting cells surrounding damaged inner hair cells (Fig. 8). At this time point, inner hair cells exhibited pyknotic nuclei, indicating cell damage and death (Fig. 8A), along with missing or disrupted stereocilial hair bundles (Fig. $8 B$ ). ERK1/2 activation was typically observed in clusters of phalangeal and border cells surrounding the inner hair cells. In some cases, single activated supporting cells could be observed (Fig. 8C,D). In almost all cases, the activated cells surrounded pyknotic inner hair cells. Thus, neomycin and mechanical damage produced a similar pattern of ERK1/2 activation.

The role of damage-induced ERK1/2 activation is controversial. For the most part, it has been suggested to be a prosurvival factor (Xia et al., 1995; Guyton et al., 1996; Arthur et al., 2006); however, there is also evidence that it can promote cell death (Stanciu et al., 2000; Sperandio et al., 2004; Subramaniam et al., 2004; Chen et al., 2005). We tested whether ERK1/2 activation in 
supporting cells plays a role in hair cell death by inhibiting MEK1/2. When neomycin application was combined with U0126 $(10 \mu \mathrm{M})$, there was a significant decrease in the number of pyknotic hair cells compared with neomycin alone (Fig. 8E,F). In control untreated explants, there are $\sim 11$ IHCs per $100 \mu \mathrm{m}$ section of a cochlear turn. In explants treated with neomycin for $8 \mathrm{~h}$, there were $4.9 \pm 1.2 \mathrm{py}-$ knotic IHCs per $100 \mu \mathrm{m}$, whereas in the presence of U0126, the number of pyknotic IHCs was significantly reduced to $1.0 \pm 0.4$ per $100 \mu \mathrm{m}$. No activation of ERK1/2 was observed in the U0126treated explants (data not shown). Coapplication of U0124 (an inactive analog of U0126) with neomycin had no effect on the number of pyknotic IHCs. These data show that preventing the activation of ERK1/2 during hair cell damage had a protective effect, significantly reducing inner hair cell loss, suggesting that the activation of ERK1/2 in supporting cells is a mediator of hair cell death.

\section{A single transient activation of ERK1/2 in supporting cells is not sufficient to cause the death of surrounding hair cells}

If ERK1/2 activation in supporting cells is sufficient for hair cell death, we might expect that mechanical damage should result in the death of hair cells bordering the damage site. In attempt to address this question, cochlear explants were laser ablated (which allowed sterility to be maintained) and returned to the incubator for $24 \mathrm{~h}$ before fixation. DAPI labeling of nuclei was used to determine the number of hair cells over a distance of $65 \mu \mathrm{m}$ from the edge of the damage site along the hair cell rows. Undamaged explants acted as controls and were fixed at the same time point. The number of IHCs did not significantly differ between undamaged controls ( $7.4 \pm 0.6$ cells per $65 \mu \mathrm{m}$; three explants) and damaged explants $(7.3 \pm 0.8$ cells per $65 \mu \mathrm{m}$; eight lesions from three explants). However, the number of OHCs was significantly reduced from $25.1 \pm 1.1$ cells per $65 \mu \mathrm{m}$ to $21.4 \pm 1.4$ cells per 65 $\mu \mathrm{m}$. However, it was also noticeable that over the $24 \mathrm{~h}$ period there was a wound-healing response that effectively pulled hair cells in toward the healed area (Meyers and Corwin, 2007). Both the initial damage and subsequent wound healing occurred primarily in the outer hair cell region, and there was little alteration in the inner hair cell region. However, ERK1/2 activation occurred in both of those regions (Fig. 1). Thus, the simplest explanation is that cell rearrangements resulting from wound healing account for the small reduction in outer hair cell numbers recorded away from the damage site. The lack of effect in the inner hair cell region is consistent with this interpretation. Thus, a single transient activation of ERK1/2 in supporting cells alone does not appear to be sufficient to precipitate hair cell death as observed in neomycin-treated explants, indicating the involvement of other factors or signals.

\section{Discussion}

Here we demonstrate that ERK1/2 activation is a common damage signaling event in the neonatal cochlea. Damage-induced ERK1/2 activation occurs in a cell-specific pattern in response to mechanical damage, laser ablation, and neomycin-induced hair cell damage/death. Furthermore, we show that damage-induced ERK1/2 activation depends on release of extracellular ATP and a signaling component spread via, or at least requiring, functional gap junctions or connexin hemichannels. Extracellular application of ATP is sufficient to activate ERK1/2 selectively in supporting cells. ATP is known to underlie mechanically induced $\mathrm{Ca}^{2+}$ waves in a number of tissues, including the cochlea (Newman, 2001; Gale et al., 2004). Here, damage generates a $\mathrm{Ca}^{2+}$ wave in the hair cell region, and a significant fraction of this wave results from $\mathrm{Ca}^{2+}$ influx. Activation and spread of the ERK1/2 signal through the hair cell region is partially dependent on $\mathrm{Ca}^{2+}$ influx. Finally, inhibiting the neomycin-induced activation of ERK1/2 reduces the number of pyknotic inner hair cells, suggesting that, in the neonatal rat cochlea, ERK1/2 activation in supporting cells promotes hair cell death.

\section{Features and mechanisms of damage-induced ERK1/2} activation in cochlear explants

ERK1/2 activation resulting from cell damage has been described in cell lines and in homogenous cell cultures (Dieckgraefe et al., 1997; Neary et al., 2003; Yang et al., 2004). Less is known about ERK1/2 activation in tissues and organs. Excess light exposure can activate ERK1/2 in photoreceptors and surrounding Mueller cells but only in a subpopulation of neuronal cells (Liu et al., 1998). A striking feature of the ERK1/2 activation observed here was its cell specificity, with activation being restricted to Deiters' and phalangeal cells, the direct neighbors of hair cells. Block by apyrase revealed a requirement for extracellular ATP for activation, and brief ATP application was not only sufficient to activate ERK1/2 in the cochlea but also mimicked the cell-specific pattern of damage-induced activation. This suggests that certain cells possess the appropriate receptors to respond to ATP and transduce it into an ERK1/2 signal. In astrocytes, damage-induced ERK1/2 activation occurs in a $\mathrm{P} 2$ receptor- and $\mathrm{Ca}^{2+}$-dependent 

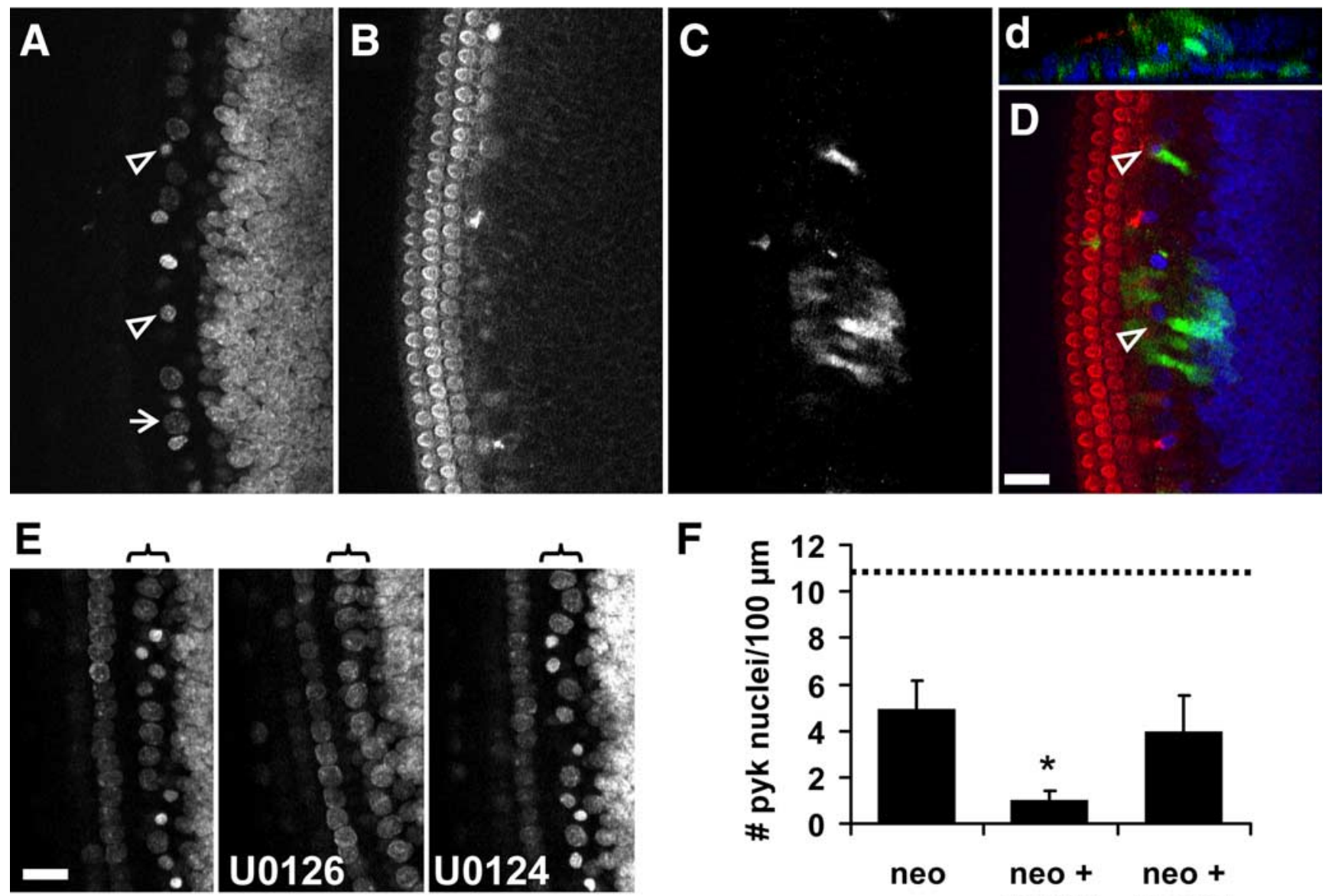

$\mathbf{F}$

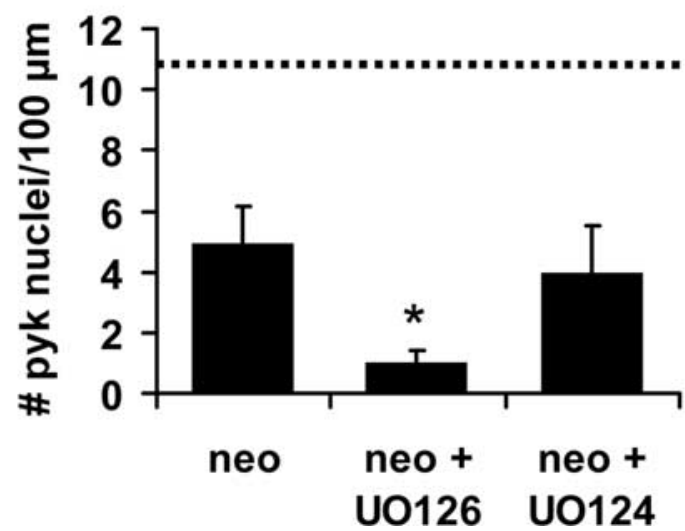

Figure 8. Blocking the activation of ERK1/2 reduces inner hair cell death in neomycin-treated cochlear cultures. $A-D$, Triple-labeled confocal optical sections from neomycin-treated (1 mM) cochlear explants focused at the level of the IHC. A, DAPI-labeled nuclei. B, F-actin in the stereocilial hair bundles. C, Activated ERK1/2.D, Three-channel merge. Arrowheads, Nuclei with condensed pyknotic chromatin; arrow, normal-appearing nucleus. $\boldsymbol{d}$, Orthogonal projection for $\boldsymbol{D}$. $\boldsymbol{E}$, Confocal $z$-stack averages of DAPI-labeled cochlear cultures treated with neomycin alone, with neomycin and U0126, and with neomycin and U0124. Brackets indicate the position of the IHC row. F, Quantification of IHC death assessed by the number of pyknotic (pyk) nuclei per $100 \mu \mathrm{m}$ cochlear turn. The dashed line indicates the number of IHCs in control untreated explants per $100 \mu \mathrm{m}$. Data are presented as mean \pm SEM; $n=12$ [neomycin (neo)]; $n=11$ (neomycin plus U0126); $n=3$ (neomycin plus U0124); Student's $t$ test; ${ }^{*} p<0.05$. Scale bars, $20 \mu \mathrm{m}$.

manner (Neary et al., 2003). We found that part of the ERK1/2 signal in the cochlea depends on $\mathrm{Ca}^{2+}$ influx, indicating a role for the damage-induced $\mathrm{Ca}^{2+}$ wave in this signaling and implicating ionotropic $\mathrm{P} 2 \mathrm{X}$ receptors as potential mediators.

However, apyrase only partially blocked ERK1/2 activation, suggesting that ATP release was not the only mechanism for damage-induced ERK1/2 activation. The ERK1/2 activity remaining in the presence of apyrase was blocked using the gap junction inhibitor carbenoxolone. Cochlear supporting cells are connected by numerous gap junction plaques (Forge et al., 2003), and therefore a damage-induced signal could spread through the network of gap junctions, contributing to the observed pattern of ERK1/2 activation. Possible mediators of a gap junction signal are $\mathrm{Ca}^{2+}, \mathrm{IP}_{3}$, cAMP, and cGMP (Bevans et al., 1998; Ayad et al., 2006; Bedner et al., 2006). Treating organ explants with BAPTA-AM failed to prevent ERK1/2 activation; thus global $\mathrm{Ca}^{2+}$ changes via gap junctions can be ruled out here. $\mathrm{IP}_{3}$ is known to permeate through supporting cell gap junctions (Beltramello et al., 2005); however, the lack of effect of BAPTA again precludes this as a signal mediator. We know little about the activity of cAMP and cGMP in the cochlea, but these second messengers can modulate ERK1/2 activity in other systems (Vossler et al., 1997; Stork and Schmitt, 2002; Zaragoza et al., 2002; Yamazaki et al., 2005). Another possibility, consistent with the effect of carbenoxolone, is that connexin hemichannels are required for activation of the ERK1/2 signal. Connexin hemichannels have been implicated in the spread of damageinduced $\mathrm{Ca}^{2+}$ signals in the cochlea (Gale et al., 2004; Piazza et al., 2007), and cochlear ATP levels are modulated by hemichannel blockers, such as carbenoxolone (Zhao et al., 2005; Thompson et al., 2006). Open hemichannels can mediate the release of ATP (Stout et al., 2002; Pearson et al., 2005) and permit $\mathrm{Ca}^{2+}$ influx. A significant proportion of the damage-induced $\mathrm{Ca}^{2+}$ wave in the hair cell region results from $\mathrm{Ca}^{2+}$ influx, and in the absence of $\mathrm{Ca}^{2+}$, the spread of the ERK1/2 signal is significantly reduced, both of which can be explained by the activation of hemichannels or pannexins (Bruzzone et al., 2005). Whether similar events occur in the adult cochlea during hair cell damage remains to be determined. However, it is known that cochlear ablation triggers the activation of ERK1/2 in the auditory brainstem (Suneja and Potashner, 2003), and Deiters' cells continue to express P2X receptors into adulthood (Housley et al., 1999).

Spatiotemporal profile of damage-induced ERK1/2 activation Preventing ERK1/2 activation in mammalian and avian vestibular epithelia reduced the proliferative activity of supporting cells in vitro, indicating a role in responding to hair cell loss (Montcouquiol and Corwin, 2001; Witte et al., 2001). We show that 
ERK1/2 activation in supporting cells is a common response to damage in the mammalian cochlea. The downstream signaling programs activated by ERK1/2 depend on the duration and its subcellular localization. In PC12 cells, transient ERK1/2 activation results in proliferation, whereas sustained activation induces differentiation (Cowley et al., 1994; Traverse et al., 1994). In fibroblasts, a transient signal maintains their differentiated state, whereas sustained activation leads to transformation and tumor formation (Cowley et al., 1994; Mansour et al., 1994). In cochlear explants, we observed transient ERK1/2 activation in responding cells; however, activation in cells close to the damage site was prolonged. Thus, different downstream programs could be activated in cells depending on their proximity to the original damage site or damaged cell. Furthermore, we observed localization of activated ERK1/2 in both the cytoplasm and the nucleus. In the cytoplasm, ERK1/2 target molecules involved in migration or cytoskeletal remodeling (Klemke et al., 1997; Nguyen et al., 1999; Glading et al., 2004; Mitsushima et al., 2004). Cytoplasmic ERK1/2 can also modulate gap junction function (Brandes et al., 2002) and activate phospholipase A2 (Lin et al., 1993; van Rossum et al., 2001). Translocation of phosphorylated ERK1/2 dimers to the nucleus is required for the activation of transcription factors, such as Elk-1, leading to expression of immediate early genes, including c-fos and junB (Hodge et al., 1998). These AP-1 family members are upregulated after noise trauma to the cochlea (Matsunobu et al., 2004), and in large-scale gene expression profiles of damaged and regenerating avian hair cell epithelia, AP-1 was one of seven clearly identifiable transcription factors (Hawkins et al., 2007).

\section{ERK1/2 activation in supporting cells promotes hair cell death in the cochlea}

Selectively damaging hair cells with neomycin produced a similar pattern, in which supporting cells surrounding hair cells exhibited ERK1/2 activation. Using this paradigm, we were able to test the function of ERK1/2 activation. MEK1/2 inhibition significantly reduced the number of pyknotic inner hair cells measured after $8 \mathrm{~h}$ of neomycin. It is possible that ERK $1 / 2$ activation is directly involved in cell death pathways within hair cells. However, (1) we observed little or no activation of ERK1/2 in hair cells [counts of ERK1/2 activated cells from 11 different cochlear explants showed that $~ 96 \%$ were supporting cells, with the remaining likely to be hair cells (data not shown)]; and (2) in experiments using hair cells isolated from guinea pigs, there was no effect of ERK $1 / 2$ inhibition on the time course of cell death after neomycin exposure (our unpublished observations). When we combine the cell specificity of ERK1/2 activation with the protection observed with MEK1/2 inhibition, the simplest, yet surprising, conclusion is that, under certain conditions, supporting cells act to promote hair cell death. On this basis, we suggest that after reaching a critical stage of toxicity, hair cells signal their impaired integrity through the release of ATP to surrounding supporting cells, thereby activating ERK1/2 and triggering a wound repair response. Supporting cells are known to be essential for the repair of damaged hair cell epithelia (Forge and Li, 2000; Gale et al., 2002; Abrashkin et al., 2006; Hordichok and Steyger, 2007), but such a direct role in hair cell death has not been shown. Such a wound repair response would require the induction of cell motility via ERK1/2 activation, and this would be consistent with observations of cells migrating in an ERK1/2dependent manner (Huang et al., 2004). However, a single transient activation of ERK1/2 alone does not appear to be sufficient to pre- cipitate hair cell death, indicating the requirement of another factor(s) or perhaps the repetitive activation of ERK1/2. Additional investigation is required to determine whether similar events are triggered in supporting cells in the adult cochlea and whether the mechanism described here contributes to hair cell death described in vivo. Given that noise trauma increases the endolymphatic concentration of ATP in guinea pigs (Munoz et al., 2001), it is possible that the cell death resulting from such trauma is, at least to some extent, ERK1/2- and supporting cell-mediated. Whether ERK1/2 are potential therapeutic targets is debatable, because long-term blockade of MEK1/2 ( $\sim 48 \mathrm{~h}$ ) causes hair cell death (Battaglia et al., 2003), suggesting that basal levels of ERK1/2 activation in hair cells are crucial for survival. In summary, damage induced the cell-specific activation of ERK1/2 via release of ATP, and blocking ERK1/2 activation abrogated neomycin-induced hair cell death. It is possible that under certain conditions, the drive for supporting cells to maintain the epithelial barrier results in them directly promoting hair cell death. Additional work is required to understand this new active role for supporting cells and the complex nature of cell-cell signaling in hair cell epithelia.

\section{References}

Abrashkin KA, Izumikawa M, Miyazawa T, Wang CH, Crumling MA, Swiderski DL, Beyer LA, Gong TW, Raphael Y (2006) The fate of outer hair cells after acoustic or ototoxic insults. Hear Res 218:20-29.

Arthur DB, Georgi S, Akassoglou K, Insel PA (2006) Inhibition of apoptosis by $\mathrm{P} 2 \mathrm{Y} 2$ receptor activation: novel pathways for neuronal survival. J Neurosci 26:3798-3804.

Ayad WA, Locke D, Koreen IV, Harris AL (2006) Heteromeric, but not homomeric, connexin channels are selectively permeable to inositol phosphates. J Biol Chem 281:16727-16739.

Battaglia A, Pak K, Brors D, Bodmer D, Frangos JA, Ryan AF (2003) Involvement of ras activation in toxic hair cell damage of the mammalian cochlea. Neuroscience 122:1025-1035.

Bedner P, Niessen H, Odermatt B, Kretz M, Willecke K, Harz H (2006) Selective permeability of different connexin channels to the second messenger cyclic AMP. J Biol Chem 281:6673-6681.

Beltramello M, Piazza V, Bukauskas FF, Pozzan T, Mammano F (2005) Impaired permeability to Ins $(1,4,5) \mathrm{P} 3$ in a mutant connexin underlies recessive hereditary deafness. Nat Cell Biol 7:63-69.

Bevans CG, Kordel M, Rhee SK, Harris AL (1998) Isoform composition of connexin channels determines selectivity among second messengers and uncharged molecules. J Biol Chem 273:2808-2816.

Brandes RP, Popp R, Ott G, Bredenkotter D, Wallner C, Busse R, Fleming I (2002) The extracellular regulated kinases (ERK) $1 / 2$ mediate cannabinoid-induced inhibition of gap junctional communication in endothelial cells. Br J Pharmacol 136:709-716.

Bruzzone R, Barbe MT, Jakob NJ, Monyer H (2005) Pharmacological properties of homomeric and heteromeric pannexin hemichannels expressed in Xenopus oocytes. J Neurochem 92:1033-1043.

Chardin S, Romand R (1995) Regeneration and mammalian auditory hair cells. Science 267:707-711.

Chen CH, Wang WJ, Kuo JC, Tsai HC, Lin JR, Chang ZF, Chen RH (2005) Bidirectional signals transduced by DAPK-ERK interaction promote the apoptotic effect of DAPK. EMBO J 24:294-304.

Cowley S, Paterson H, Kemp P, Marshall CJ (1994) Activation of MAP kinase kinase is necessary and sufficient for PC12 differentiation and for transformation of NIH 3T3 cells. Cell 77:841-852.

Dieckgraefe BK, Weems DM, Santoro SA, Alpers DH (1997) ERK and p38 MAP kinase pathways are mediators of intestinal epithelial woundinduced signal transduction. Biochem Biophys Res Commun 233:389-394.

Favata MF, Horiuchi KY, Manos EJ, Daulerio AJ, Stradley DA, Feeser WS, Van Dyk DE, Pitts WJ, Earl RA, Hobbs F, Copeland RA, Magolda RL, Scherle PA, Trzaskos JM (1998) Identification of a novel inhibitor of mitogen-activated protein kinase kinase. J Biol Chem 273:18623-18632.

Forge A (1985) Outer hair cell loss and supporting cell expansion following chronic gentamicin treatment. Hear Res 19:171-182.

Forge A, Li L (2000) Apoptotic death of hair cells in mammalian vestibular sensory epithelia. Hear Res 139:97-115. 
Forge A, Schacht J (2000) Aminoglycoside antibiotics. Audiol Neurootol 5:3-22.

Forge A, Becker D, Casalotti S, Edwards J, Marziano N, Nevill G (2003) Gap junctions in the inner ear: comparison of distribution patterns in different vertebrates and assessement of connexin composition in mammals. J Comp Neurol 467:207-231.

Gale JE, Marcotti W, Kennedy HJ, Kros CJ, Richardson GP (2001) FM1-43 dye behaves as a permeant blocker of the hair-cell mechanotransducer channel. J Neurosci 21:7013-7025.

Gale JE, Meyers JR, Periasamy A, Corwin JT (2002) Survival of bundleless hair cells and subsequent bundle replacement in the bullfrog's saccule. J Neurobiol 50:81-92.

Gale JE, Piazza V, Ciubotaru CD, Mammano F (2004) A mechanism for sensing noise damage in the inner ear. Curr Biol 14:526-529.

Glading A, Bodnar RJ, Reynolds IJ, Shiraha H, Satish L, Potter DA, Blair HC, Wells A (2004) Epidermal growth factor activates m-calpain (calpain II), at least in part, by extracellular signal-regulated kinase-mediated phosphorylation. Mol Cell Biol 24:2499-2512.

Guyton KZ, Liu Y, Gorospe M, Xu Q, Holbrook NJ (1996) Activation of mitogen-activated protein kinase by $\mathrm{H} 2 \mathrm{O} 2$. Role in cell survival following oxidant injury. J Biol Chem 271:4138-4142.

Hawkins RD, Bashiardes S, Powder KE, Sajan SA, Bhonagiri V, Alvarado DM, Speck J, Warchol ME, Lovett M (2007) Large scale gene expression profiles of regenerating inner ear sensory epithelia. PLoS ONE 2:e525.

Hodge C, Liao J, Stofega M, Guan K, Carter-Su C, Schwartz J (1998) Growth hormone stimulates phosphorylation and activation of elk-1 and expression of c-fos, egr-1, and junB through activation of extracellular signalregulated kinases 1 and 2. J Biol Chem 273:31327-31336.

Hordichok AJ, Steyger PS (2007) Closure of supporting cell scar formations requires dynamic actin mechanisms. Hear Res 232:1-19.

Housley GD, Kanjhan R, Raybould NP, Greenwood D, Salih SG, Jarlebark L, Burton LD, Setz VC, Cannell MB, Soeller C, Christie DL, Usami S, Matsubara A, Yoshie H, Ryan AF, Thorne PR (1999) Expression of the P2X receptor subunit of the ATP-gated ion channel in the cochlea: implications for sound transduction and auditory neurotransmission. J Neurosci 19:8377-8388.

Huang C, Jacobson K, Schaller MD (2004) MAP kinases and cell migration. J Cell Sci 117:4619-4628.

Jagger DJ, Forge A (2006) Compartmentalized and signal-selective gap junctional coupling in the hearing cochlea. J Neurosci 26:1260-1268.

Kikuchi T, Kimura RS, Paul DL, Adams JC (1995) Gap junctions in the rat cochlea: immunohistochemical and ultrastructural analysis. Anat Embryol (Berl) 191:101-118.

Klemke RL, Cai S, Giannini AL, Gallagher PJ, de Lanerolle P, Cheresh DA (1997) Regulation of cell motility by mitogen-activated protein kinase. J Cell Biol 137:481-492.

Lackey K, Cory M, Davis R, Frye SV, Harris PA, Hunter RN, Jung DK, McDonald OB, McNutt RW, Peel MR, Rutkowske RD, Veal JM, Wood ER (2000) The discovery of potent cRafl kinase inhibitors. Bioorg Med Chem Lett 10:223-226.

Lin LL, Wartmann M, Lin AY, Knopf JL, Seth A, Davis RJ (1993) cPLA2 is phosphorylated and activated by MAP kinase. Cell 72:269-278.

Liu C, Peng M, Laties AM, Wen R (1998) Preconditioning with bright light evokes a protective response against light damage in the rat retina. J Neurosci 18:1337-1344.

Mansour SJ, Matten WT, Hermann AS, Candia JM, Rong S, Fukasawa K, Vande Woude GF, Ahn NG (1994) Transformation of mammalian cells by constitutively active MAP kinase kinase. Science 265:966-970.

Marcotti W, van Netten SM, Kros CJ (2005) The aminoglycoside antibiotic dihydrostreptomycin rapidly enters mouse outer hair cells through the mechano-electrical transducer channels. J Physiol (Lond) 567:505-521.

Matsui JI, Gale JE, Warchol ME (2004) Critical signaling events during the aminoglycoside-induced death of sensory hair cells in vitro. J Neurobiol 61:250-266.

Matsunobu T, Ogita K, Schacht J (2004) Modulation of activator protein 1/DNA binding activity by acoustic overstimulation in the guinea-pig cochlea. Neuroscience 123:1037-1043.

Meyers JR, Corwin JT (2007) Shape change controls supporting cell proliferation in lesioned mammalian balance epithelium. J Neurosci 27:4313-4325.

Mitsushima M, Suwa A, Amachi T, Ueda K, Kioka N (2004) Extracellular signal-regulated kinase activated by epidermal growth factor and cell ad- hesion interacts with and phosphorylates vinexin. J Biol Chem 279:34570-34577.

Montcouquiol M, Corwin JT (2001) Intracellular signals that control cell proliferation in mammalian balance epithelia: key roles for phosphatidylinositol-3 kinase, mammalian target of rapamycin, and S6 kinases in preference to calcium, protein kinase $C$, and mitogen-activated protein kinase. J Neurosci 21:570-580.

Munoz DJ, Kendrick IS, Rassam M, Thorne PR (2001) Vesicular storage of adenosine triphosphate in the guinea-pig cochlear lateral wall and concentrations of ATP in the endolymph during sound exposure and hypoxia. Acta Otolaryngol 121:10-15.

Neary JT, Kang Y, Willoughby KA, Ellis EF (2003) Activation of extracellular signal-regulated kinase by stretch-induced injury in astrocytes involves extracellular ATP and P2 purinergic receptors. J Neurosci 23:2348-2356.

Newman EA (2001) Propagation of intercellular calcium waves in retinal astrocytes and Muller cells. J Neurosci 21:2215-2223.

Nguyen DH, Catling AD, Webb DJ, Sankovic M, Walker LA, Somlyo AV, Weber MJ, Gonias SL (1999) Myosin light chain kinase functions downstream of Ras/ERK to promote migration of urokinase-type plasminogen activator-stimulated cells in an integrin-selective manner. J Cell Biol 146:149-164.

Pearson RA, Dale N, Llaudet E, Mobbs P (2005) ATP released via gap junction hemichannels from the pigment epithelium regulates neural retinal progenitor proliferation. Neuron 46:731-744.

Piazza V, Ciubotaru CD, Gale JE, Mammano F (2007) Purinergic signalling and intercellular $\mathrm{Ca} 2+$ wave propagation in the organ of Corti. Cell Calcium 41:77-86.

Pirvola U, Xing-Qun L, Virkkala J, Saarma M, Murakata C, Camoratto AM, Walton KM, Ylikoski J (2000) Rescue of hearing, auditory hair cells, and neurons by CEP-1347/KT7515, an inhibitor of c-Jun N-terminal kinase activation. J Neurosci 20:43-50.

Raphael Y, Altschuler RA (1991) Scar formation after drug-induced cochlear insult. Hear Res 51:173-183.

Richardson GP, Russell IJ (1991) Cochlear cultures as a model system for studying aminoglycoside induced ototoxicity. Hear Res 53:293-311.

Sachsenmaier C, Radler-Pohl A, Zinck R, Nordheim A, Herrlich P, Rahmsdorf HJ (1994) Involvement of growth factor receptors in the mammalian UVC response. Cell 78:963-972.

Santos-Sacchi J (1986) Dye coupling in the organ of Corti. Cell Tissue Res 245:525-529.

Sperandio S, Poksay K, de Belle I, Lafuente MJ, Liu B, Nasir J, Bredesen DE (2004) Paraptosis: mediation by MAP kinases and inhibition by AIP-1/ Alix. Cell Death Differ 11:1066-1075.

Stanciu M, Wang Y, Kentor R, Burke N, Watkins S, Kress G, Reynolds I, Klann E, Angiolieri MR, Johnson JW, DeFranco DB (2000) Persistent activation of ERK contributes to glutamate-induced oxidative toxicity in a neuronal cell line and primary cortical neuron cultures. J Biol Chem 275:12200-12206.

Stork PJ, Schmitt JM (2002) Crosstalk between cAMP and MAP kinase signaling in the regulation of cell proliferation. Trends Cell Biol 12:258-266.

Stout CE, Costantin JL, Naus CC, Charles AC (2002) Intercellular calcium signaling in astrocytes via ATP release through connexin hemichannels. J Biol Chem 277:10482-10488.

Subramaniam S, Zirrgiebel U, von Bohlen Und Halbach O, Strelau J, Laliberte C, Kaplan DR, Unsicker K (2004) ERK activation promotes neuronal degeneration predominantly through plasma membrane damage and independently of caspase-3. J Cell Biol 165:357-369.

Suneja SK, Potashner SJ (2003) ERK and SAPK signaling in auditory brainstem neurons after unilateral cochlear ablation. J Neurosci Res 73:235-245.

Thompson RJ, Zhou N, MacVicar BA (2006) Ischemia opens neuronal gap junction hemichannels. Science 312:924-927.

Traverse S, Seedorf K, Paterson H, Marshall CJ, Cohen P, Ullrich A (1994) EGF triggers neuronal differentiation of PC12 cells that overexpress the EGF receptor. Curr Biol 4:694-701.

van Rossum GS, Klooster R, van den Bosch H, Verkleij AJ, Boonstra J (2001) Phosphorylation of $\mathrm{p} 42 / 44$ (MAPK) by various signal transduction pathways activates cytosolic phospholipase $\mathrm{A}(2)$ to variable degrees. J Biol Chem 276:28976-28983.

Vossler MR, Yao H, York RD, Pan MG, Rim CS, Stork PJ (1997) cAMP 
activates MAP kinase and Elk-1 through a B-Raf- and Rap1-dependent pathway. Cell 89:73-82.

Wang J, Van De Water TR, Bonny C, de Ribaupierre F, Puel JL, Zine A (2003) A peptide inhibitor of $\mathrm{c}$-Jun $\mathrm{N}$-terminal kinase protects against both aminoglycoside and acoustic trauma-induced auditory hair cell death and hearing loss. J Neurosci 23:8596-8607.

Wang Y, Hirose K, Liberman MC (2002) Dynamics of noise-induced cellular injury and repair in the mouse cochlea. J Assoc Res Otolaryngol 3:248-268.

Witte MC, Montcouquiol M, Corwin JT (2001) Regeneration in avian hair cell epithelia: identification of intracellular signals required for S-phase entry. Eur J Neurosci 14:829-838.

Xia Z, Dickens M, Raingeaud J, Davis RJ, Greenberg ME (1995) Opposing effects of ERK and JNK-p38 MAP kinases on apoptosis. Science 270:1326-1331.
Yamazaki M, Chiba K, Mohri T (2005) Fundamental role of nitric oxide in neuritogenesis of PC12h cells. Br J Pharmacol 146:662-669.

Yang L, Cranson D, Trinkaus-Randall V (2004) Cellular injury induces activation of MAPK via P2Y receptors. J Cell Biochem 91:938-950.

Zaragoza C, Soria E, Lopez E, Browning D, Balbin M, Lopez-Otin C, Lamas S (2002) Activation of the mitogen activated protein kinase extracellular signal-regulated kinase 1 and 2 by the nitric oxidecGMP-cGMP-dependent protein kinase axis regulates the expression of matrix metalloproteinase 13 in vascular endothelial cells. Mol Pharmacol 62:927-935.

Zhao HB, Yu N, Fleming CR (2005) Gap junctional hemichannel-mediated ATP release and hearing controls in the inner ear. Proc Natl Acad Sci USA 102:18724-18729. 